ISSN: 2238-8052

\title{
REDES CURTAS DE COMERCIALIZAÇÃO: A PROXIMIDADE POLÍTICA, PESSOAL E ESPACIAL DA ARTICULAÇÃO ENTRE O RURAL E O URBANO
}

\author{
REDES CORTAS DE COMERCIALIZACIÓN: LA PROXIMIDAD POLÍTICA, PERSONAL Y ESPACIAL EN \\ LA ARTICULACIÓN TERRITORIAL ENTRE LO RURAL Y LO URBANO
}

Marcos Aurélio SAQUET ${ }^{1}$

Raquel MEIRA ${ }^{2}$

Artigo recebido em 24/04/2017 e aceito em 25/06/2017

Palavras-chave:
Rede
Proximidade
Território
Resistência

Descriptores:

Ren

Proximidad

Territorio

Resistencia

\section{R E S U M O}

Neste texto, socializamos os principais resultados que conseguimos sobre as redes curtas de comercialização ao estudar as práticas camponesas agroecológicas em seis municípios do Sudoeste do Paraná, evidenciando a abordagem territorial e reticular adotada, os princípios do campesinato e da Agroecologia, juntamente com as feiras livres, ou seja, os sujeitos, os produtos e os mecanismos de organização política e venda, centrados nas relações próximas, política, pessoal e espacialmente. Este processo está na base de uma das formas de articulação entre o rural e o urbano, na formação territorial com base numa resistência política e cultural ao agronegócio.

\section{R E S U M E N}

En este texto, socializamos los principales resultados que hemos conseguido cuanto las redes cortas de comercialización al estudiar las practicas campesinas agroecológicas en los seis municipios de lo Sudoeste do Paraná, en que hemos evidenciado el abordaje territorial y reticular adoptada, los principios de campesinado y de la Agroecología, juntamente con las ferias libres, o sea, los sujetos, los productos y los mecanismos de organización política y venda, centrados en las relaciones próximas, políticas, personales y espaciales. Este proceso está en la base de una de las formas de articulación entre lo rural y lo urbano, en la formación territorial con base en una resistencia política y cultural al agronegocio.

\section{INTRODUÇÃO}

Este texto é um dos resultados da nossa pesquisa sobre a agricultura camponesa (agro)ecológica em seis municípios do Sudoeste do Paraná (Ampére, Flor da Serra do Sul, Francisco Beltrão, Itapejara d'Oeste, Marmeleiro e Verê), processo realizado com financiamentos do CNPq (Edital Universal 14/2013) e da Fundação Araucária (Edital Universal 24/2012), bem como da nossa bolsa de produtividade em pesquisa. Um dos nossos objetivos específicos refere-se ao estudo da gestão

\footnotetext{
${ }^{1}$ Universidade Estadual do Oeste do Paraná. Grupo de Estudos Territoriais. E-mail: saquetmarcos@hotmail.com.

${ }^{2}$ Universidade Estadual do Oeste do Paraná. E-mail: rakelmeira@hotmail.com.
} 
familiar, verificando como os camponeses agroecológicos tomam as decisões e como estão organizados politicamente para viabilizar a comercialização, identificando as principais redes que efetivam para comercializar.

Para tal, optamos por uma concepção de abordagem que consideramos histórico-crítica, relacional, reticular (redes de circulação e comunicação) e pluridimensional (RAFFESTIN, 1993 [1980]; DEMATTEIS, 1985; THOMPSON, 1998 [1991]; SHANIN, 2005; DANSERO e ZOBEL, 2007; MAGNAGHI, 1976, 2000; FERNANDES, 2008, 2009; SAQUET, 2003 [2001], 2007, 2011, 2015 [2011]), centrada na relação sociedade-natureza. As unidades produtivas e de vida camponesas (SHANIN, 1971, 2005) são compreendidas como territórios de produção, existência, luta e resistência (THOMPSON, 1998 [1991]; ESCOBAR, 1999; MARQUES, 2000, 2004; FERNANDES, 1996, 2007, 2008), com singularidades econômicas, políticas, culturais e ambientais, que acontecem simultaneamente como relações conflituosas - de poder e disputas inerentes à vida em sociedade - que se territorializam no tempo e no espaço. Os procedimentos utilizados são a pesquisa bibliográfica e documental, a aplicação dos questionários, a realização das entrevistas, a coleta e análise dos dados secundários (IBGE) e a representação cartográfica.

Sucintamente, também é importante fazer outros três esclarecimentos:

a) 0 campesinato efetiva-se como uma classe social que sobrevive em meio às contradições da expansão capitalista (MARX, 2000 [1852]; POLANYI, 2000 [1944]; CHAYANOV, 1974; MARTINS, 1981; SHANIN, 1983, 2005, 2008; OLIVEIRA, 1986, 1991, 2004; MARQUES, 2004, 2008; GUZMÁN, MOLINA, 2005; FERNANDES, 2014; BARTRA, 2014), territorializando-se historicamente de distintas maneiras, como por meio das práticas agroecológicas, adaptando-se às condições sociais e naturais produzindo alimentos sem insumos químicos, valorizando os conhecimentos repassados de geração em geração e a cooperação, como ocorre nos munícipios estudados. Na agricultura camponesa, ocorre a reprodução de relações não-capitalistas de produção (MARTINS, 1981, 1986 [1979]; OLIVEIRA, 1981, 1986, 1991, 1999, 2004) ou de relações não especificamente capitalistas (TAVARES DOS SANTOS, 1978; SAQUET, 1997, 2003 [2001]), com cooperação e solidariedade, conflitos e disputas, reciprocidade e inserção no mercado.

b) A produção agroecológica concretiza-se como práxis da agricultura camponesa diferenciada, conforme indicam importantes autores como Altieri (1998, 2012 [2002a], 2012 [2002b], 2012 [2008]), Gliessman (2000) e Guzmán e Molina (2005), pois há mais autonomia decisória por parte da família, manejo ecológico na produção, valorização do conhecimento do agricultor e da sua cultura historicamente construída. O camponês agroecológico é um sujeito social, histórico, trabalha e vive sob princípios específicos e vinculados à relação cotidiana que mantém com a terra.

c) As redes curtas, por meio das territorialidades entre o campo e a cidade, entre o urbano e o rural, muitas vezes, estão centradas em relações de confiança entre produtores e consumidores, são 
um dos componentes centrais do desenvolvimento local, colocando à disposição dos consumidores produtos locais, às vezes típicos, com atributos culturais e ecológicos singulares. Assim, entendemos as redes curtas ou circuits courts, por meio da proximidade geográfica e institucional (CHAFFOTTE e CHIFFOLEAU, 2007; AUBRY e CHIFFOLEAU, 2009; DAROLT, 2013; CHÁVEZ e SALCIDO, 2014; SANZ, 2014) ou short-circuiting (RENTING, MARSDEN e BANKS, 2003), como processo de interação para produzir e, especialmente, para comercializar.

Alguns dos princípios mais importantes da Agroecologia são: a) ampliação e preservação da biodiversidade; b) aproveitamento de sinergismos próprios dos componentes biológicos e dos recursos de cada unidade produtiva, trabalhando com o controle biológico de pragas; c) recuperação do solo degradado e sua proteção com manejo adequado que garanta matéria orgânica para nutrição das plantas; d) produção de alimentos sem a utilização de insumos químicos; e) contribuição para a conservação das águas, das plantas e dos animais; f) aumento da capacidade de uso múltiplo do território (ALTIERI, 1998) com o favorecimento da diversificação da produção e com as agroflorestas; g) reciclagem de nutrientes e da matéria orgânica; h) preservação das identidades culturais, valorizando o conhecimento dos agricultores, sua participação nos processos decisórios e favorecendo o uso eficaz dos recursos de cada unidade produtiva; i) tentativa de fortalecer a comercialização direta com o consumidor em mercados locais (ALTIERI, 1998, 2012 [2002a]; GLIESSMAN, 2000; ARRIEL SAQUET et al, 2005).

Desse modo, as feiras livres destacam-se como importantes atividades entre as práticas agroecológicas e para a economia familiar dos camponeses, efetivadas a partir da auto-organização e identidade política entre os produtores e, ao mesmo tempo, da eliminação dos intermediários entre os produtores e os consumidores. Assim, as feiras livres ecológicas vêm ganhando força no Brasil, principalmente no âmbito das unidades de produção familiar como forma de resistência política, como destacam Godoy e Anjos:

[...] as feiras livres têm desempenhado um papel muito importante na consolidação econômica e social, especialmente da agricultura familiar sob o ponto de vista do feirante, representando também um espaço público, sócio-econômico e cultural, extremamente dinâmico e diversificado sob o ponto de vista do consumidor (GODOY e ANJOS, 2007, p. 364).

A origem das feiras não é recente, muitas delas são parte do processo de existência de pequenas cidades no território brasileiro. Nas feiras perpassam atividades e diversos valores dos sujeitos frequentadores e, nelas, também fica evidente que o modo de vida camponês se materializa na cidade, reproduzindo-se aspectos identitários (SANTOS et. al, 2014).

Para Godoy e Anjos (2007), as feiras livres ecológicas, no Brasil, constituem-se a partir de algumas características principais, como as relações que caracterizam um diversificado conjunto de ocupações, fluxos e mercadorias, centradas no trabalho dos membros de cada família. Trata-se, portanto, de uma organização social e territorial específica, com territorialidades e temporalidades 
também singulares, objetivando-se como redes curtas e formas da articulação entre o rural e o urbano. Há, aí, intercâmbio de saberes e experiências: o consumidor reproduz e socializa aspectos da sua vida urbana e, o agricultor, faz o mesmo a partir da sua vida cotidiana (GODOY e ANJOS, 2007).

Este canal de comercialização tem uma característica muito particular de interação, proporcionando a aproximação e a troca de saberes, não apenas entre o rural-urbano, mas, sobretudo do próprio rural. 0 "espaço-feira" tem proporcionado o conhecimento recíproco dos agricultores e das suas experiências, fato este que dificilmente poderia ocorrer se fossem utilizados outros canais de comercialização mais individualizados (GODOY e ANJOS, 2007, p. 366; grifo do original).

As feiras também possuem outras características marcantes, principalmente as orgânicas. Muitas vezes, são

Um lugar colorido, movimentado e cheio de sons, na primeira vez que nos deparamos com esses espaços já que sua forma esconde uma estrutura diversa e singular, cujos processos e funções se materializam numa paisagem complexa. É singular o visual das feiras, aquele visual colorido de frutas, legumes, roupas etc., iluminados pela luz solar que se infiltra através da cobertura das lonas, frestas ou espaços entre os amontoados de barracas (SANTOS et. al, 2014, p. 64).

No "interior" da feira livre afloram relações diversas, econômicas - de comercialização -, solidárias, conversas, lanches, diversões e até mesmo conflitos e disputas. Desse modo, podemos entendê-las, consoante já mencionamos, como territórios de comercialização, diálogos, intercâmbios, cooperações e resistência, sobretudo dos camponeses que, normalmente, auto-organizados, lutam para se reproduzir como tal, seja produzindo convencionalmente (com insumos químicos), seja produzindo por meio das práticas agroecológicas.

Nos municípios estudados, percebemos que as feiras livres são fundamentais na reprodução da família camponesa, sobretudo das agroecológicas, pois esta é uma das principais formas de comercialização, consoante evidenciaremos a seguir. As demais maneiras identificadas, que assumem menor proporção e frequência, são: venda no próprio estabelecimento rural, na Associação de Produtores Agroecológicos de Verê (APAVE), na Associação dos Produtores de Vinho de Verê (APROVIVE), para o Programa de Aquisição de Alimentos (PAA) e Programa Nacional de Alimentação Escolar (PNAE), nos supermercados locais, entrega a domicílio, no Mercado do Produtor (Itapejara d'Oeste e Francisco Beltrão), nos restaurantes, num hospital e numa APAE.

\section{AS FEIRAS LIVRES COMO OBJETIVAÇÃO DA REPRODUÇÃO CAMPONESA E DA ARTICULAÇÃO ENTRE O RURAL E O URBANO}

Nos seis municípios estudados existem, atualmente, 13 feiras livres onde se vendem produtos dos agricultores. As agroecológicas são 1 de Marmeleiro, 3 de Francisco Beltrão, 1 de Flor da Serra e 2 de Ampére, conforme detalharemos na sequência. 


\title{
A feira AFAECO - AMPÉRE
}

Segundo Rech (2011), as atividades para a criação da Feira da Associação de Feirantes Agroecológicos de Ampére - PR (AFAECO), foram iniciadas em 2005, quando alguns integrantes do curso de Agroecologia, da Associação de Estudos Orientação e Assistência Rural (ASSESOAR), perceberam a necessidade de discutir formas alternativas de comercialização, como o chamado mercado justo, incentivado pelo Grupo Gestor do Território do Sudoeste do Paraná (GGETSPA), a partir dos anos 2003-2005. A ASSESOAR tem, de fato, um papel central na difusão das práticas agroecológicas no Sudoeste do Paraná e, para tal, algumas iniciativas foram fundamentais, como o Projeto Vida na Roça (a partir de 1996), a assistência técnica prestada aos associados e os cursos de Pós-médio em Agroecologia e Desenvolvimento, realizados entre 2007 e 2010, talvez mais sistemáticos e impactantes regionalmente.

Em 2006 e 2007 foram feitas reuniões de formação com a ASSESOAR, o STR, a CLAF e a Cresol o que culminou com a primeira venda com frequência quinzenal em 2008. A discussão inicial tinha a presença em torno de 35 famílias, que participavam de formação nas instituições, mas também em suas propriedades, sendo que dessas, 16 permaneceram no grupo da feira, optando por uma venda semanal dada a possibilidade em função da demanda e do aumento da produção (RECH, 2011, p. 80).

Este mesmo autor menciona que a Prefeitura Municipal de Ampére contribuía mensalmente com $\mathrm{R} \$ 1.000,00$, para ajudar na formação dos feirantes, o que incluía despesas com viagens e trabalhos técnicos. O auxílio começou a ser repassado em 2008 e foi encerrado em 2009 com a substituição do prefeito municipal.

\begin{abstract}
Quando a feira-livre iniciou as reuniões na AFAECO eram semanais, onde se fazia o acerto do caixa e as discussões de operacionalização. Com o passar do tempo se tornaram mensais, e o acerto financeiro foi sendo feito no próprio dia da venda. A presidente da ASSESOAR ressalta a importância do STR como sindicato que historicamente foi combativo, onde suas lideranças têm comprometimento com a comercialização, de modo que todos os feirantes são sócios do STR, sede das reuniões da AFAECO (RECH, 2011, p. 81).
\end{abstract}

Em 2015, os feirantes inauguraram um novo espaço para realização da feira da AFAECO, na praça central da cidade de Ampére, na quarta-feira, após as 16 horas, e aos sábados, a partir das 8 horas (Imagem 01). Ao todo, o grupo de feirantes da AFAECO tem 25 produtores e, na feira, nem todos estão periodicamente, mas enviam seus produtos para comercialização; apenas um produtor é certificado pela Rede Ecovida de Agroecologia. É comum acontecer que, quando algum agricultor tem algum impedimento para expor e vender diretamente seus produtos, isto é feito pelos colegas associados e feirantes, pelo que percebemos, com certa tranquilidade, pois cada produtor usa uma numeração escrita na etiqueta de venda dos produtos, assim eles fazem o controle do que é vendido e de quem é o produto. 
Figura 1: Feira da AFAECO - Ampére

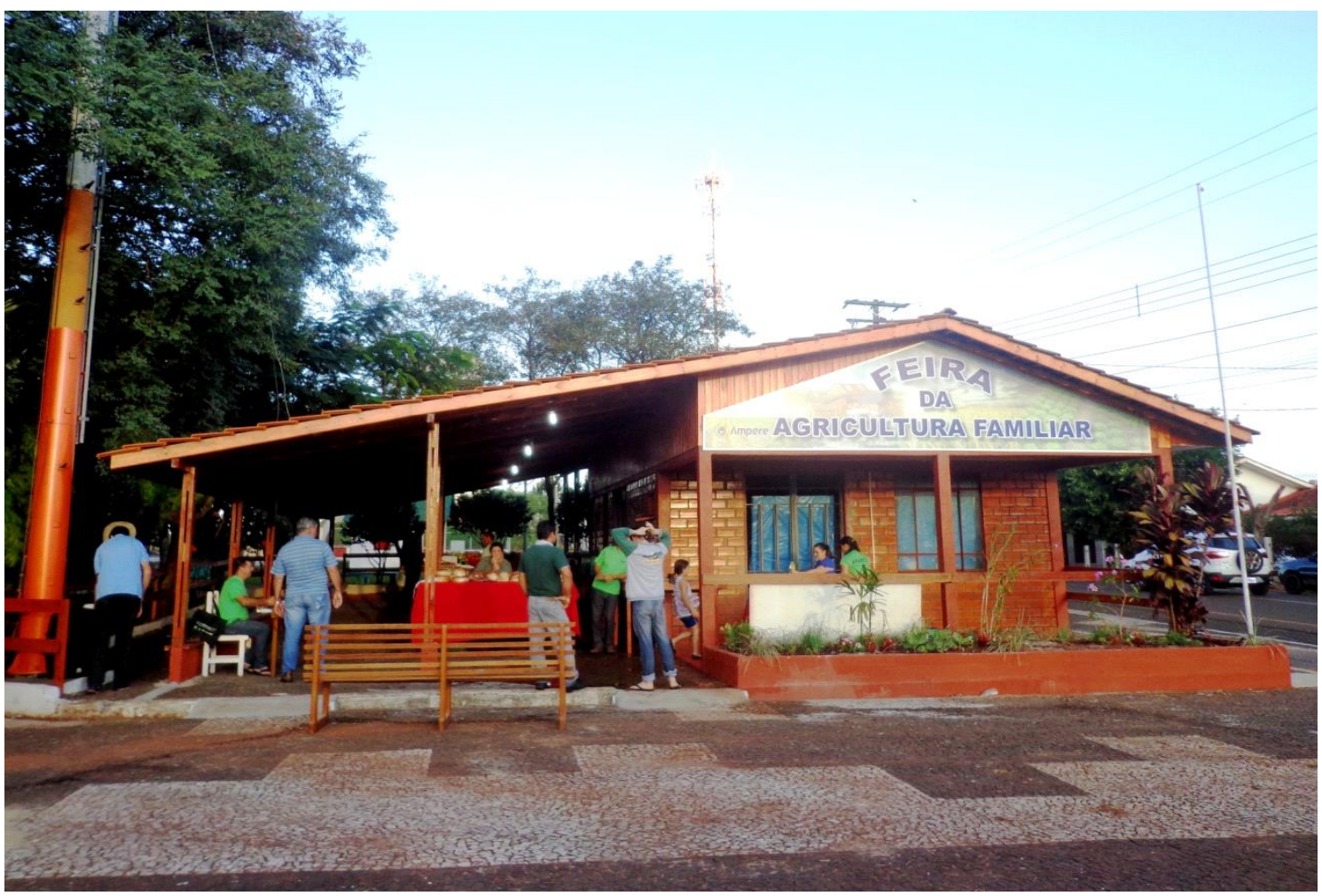

Fonte: Arquivo do GETERR/UNIOESTE - Trabalho de campo realizado em junho de 2015.

De acordo com os feirantes questionados, em março de 2016, a feira realizada aos sábados completava 8 anos e, em junho de 2016, a feira da quarta-feira tinha 1 ano de existência. Esta expansão, portanto, é bem recente, juntamente com a infraestrutura construída pela Prefeitura Municipal de Ampére. A iniciativa de realizar a feira em outro dia da semana partiu, também, dos consumidores e com a nova estrutura para realização da mesma: esta facilitou a realização da feira duas vezes por semana. Os feirantes relataram que estão satisfeitos com a feira da quarta-feira. No início, como era novidade na cidade, vendiam maior quantidade, agora as vendas diminuíram um pouco, porém, já estão adaptados ao giro de mercadorias nos diferentes dias de feira.

Os feirantes da AFAECO são todos pequenos produtores; um deles, por exemplo, tem 5,4 ha de terras, onde cultiva 2 ha com orgânicos. Das famílias que normalmente participam da feira (25), identificamos que a maioria produz de forma manual, pois grande parte da produção são panificados, bolos, verduras, legumes, frutas, queijo, feijão, tubérculos, envolvendo atividades que exigem o trabalho braçal e gerando uma produção em pequena escala. Assim, os principais produtos comercializados, semanalmente, são os seguintes: abacate, acelga, açúcar mascavo, alface americana, alface crespa, almeirão, banana nanica, banana prata, berinjela, beterraba, biscoito integral, bolacha caseira, bolacha integral, brócolis, abóbora, chuchu, couve flor, couve folha, cuca recheada, cuca simples, farinha de milho, feijão carioca, feijão preto, fruta do conde, geléias, laranja, lima, limão, 
macarrão, mandioca, melado, milho verde, ovos, pão caseiro, pão de centeio, pão de ló, pão de milho, pepino, pimenta, pimentão, pipoca, bergamota, queijo, repolho, tempero verde e vagem. Destes, apenas o feijão e o açúcar mascavo são agroecológicos (Imagem 02).

Figura 2: Produtos comercializados na Feira da AFAECO, destaque para o açúcar mascavo com certificação da Rede Ecovida.

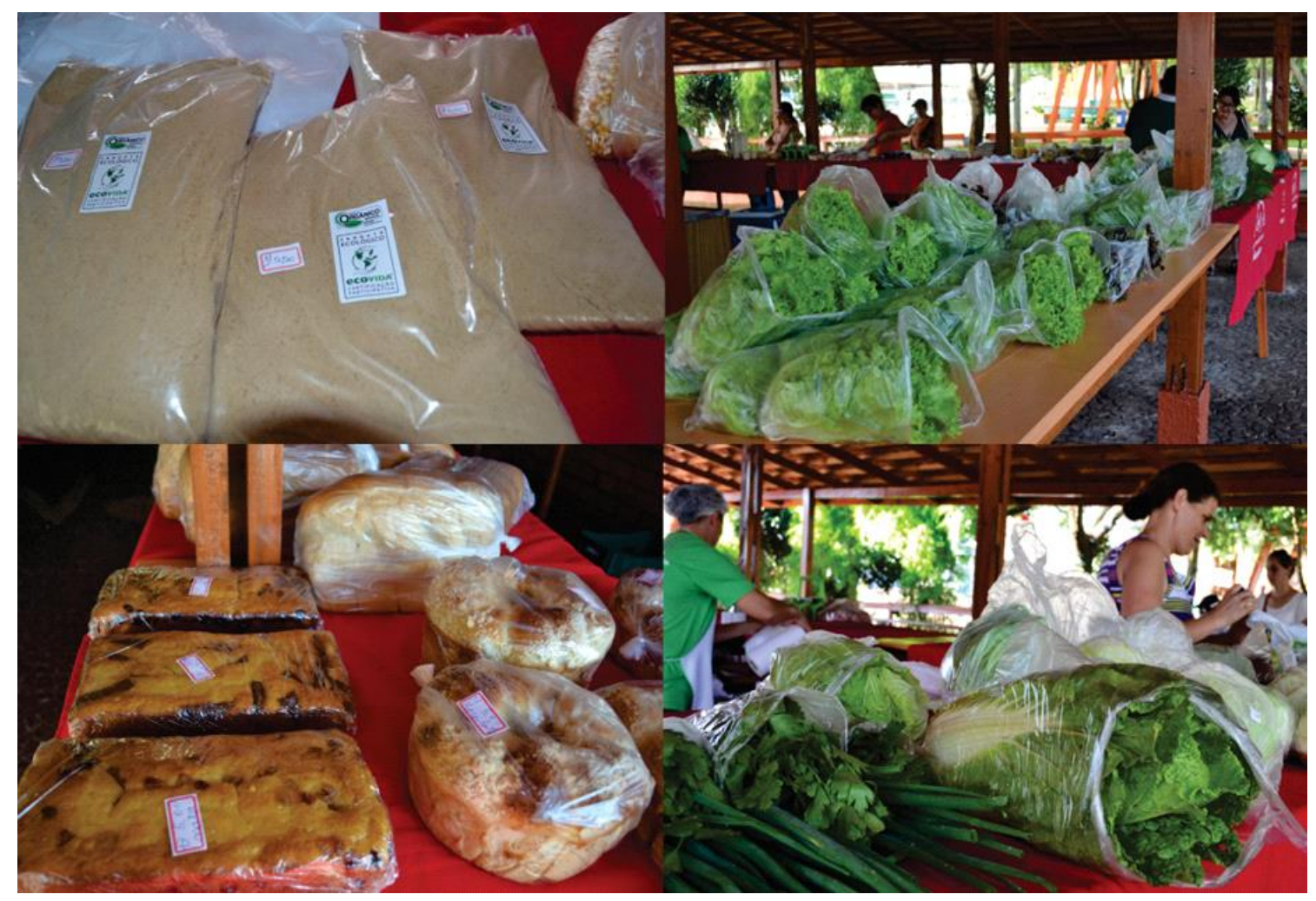

Fonte: Arquivo do GETERR/UNIOESTE - Trabalhos de campo realizados em junho e dezembro de 2015.

Esta Feira da AFAECO, a partir das visitas e entrevistas que fizemos, além de ter o maior número de produtores/vendedores, parece ser a mais organizada técnica e politicamente. Os feirantes, antes de exporem os produtos nas bancas, precisam aguardar a chegada da presidente da associação para fazer a contagem dos produtos, ou seja, há mecanismos que revelam planejamento e ordenamento para facilitar os trabalhos na feira, porém, o fato de não termos tido acesso ao estatuto da associação dificultou nossa compreensão desta associação. Eles também tentam se reunir mensalmente para conversar sobre temas dos seus interesses e têm o acompanhamento e a orientação técnica prestada pela ASSESOAR. 


\section{A feira da praça Reinaldo Simonetto - AMPÉRE}

Esta feira foi criada em 2011 e era realizada na Faculdade de Ampére (FAMPER), por isto ficou conhecida como a Feira da FAMPER, pois contava com o espaço e a ajuda de alguns professores da faculdade. Passado um tempo, os feirantes começaram a se reunir e vender seus produtos na praça Reinaldo Simonetto, Sul da cidade, pois precisavam de um espaço maior.

O professor Leomar Ripel, que participou da criação da feira, relatou que o desenvolvimento do projeto de apoio à melhoria da alimentação dos agricultores resultou em uma sobra de alimentos, com isso buscou-se uma solução para evitar o desperdício. Como já estavam pensando em uma forma para melhorar a renda das famílias, a ideia de comercializar o excedente motivou alguns agricultores, que assumiram a tarefa de vender seus produtos semanalmente. Inicialmente, a feira era formada por 7 famílias, porém, atualmente, apenas 5 participam como feirantes, sendo que uma vende pastéis. Nenhum dos feirantes possui certificação orgânica, porém, relataram que não utilizam qualquer tipo de insumo químico em seus cultivos.

Esses feirantes da praça Reinaldo Simonetto também são todos pequenos produtores familiares, comercializando sobretudo abacate, açúcar mascavo, alface americana, alface crespa, alface mimosa, alface romana, almeirão, bergamota, beterraba, bolachas, bolo, brócolis, cenoura, chicória, couve flor, couve folha, doce de leite, geléias, laranja, leite, lima, limão, mamão, mandioca, mel, melado, ovos, pão de milho, pão de queijo, pé de moleque, pimenta, queijo, rabanete, repolho, rúcula, tapioca, tempero verde e vinagre.

Um dos nossos entrevistados reside na comunidade rural de Vargem Bonita, ainda aguarda a certificação da produção que deverá ocorrer a partir da vistoria do Centro de Apoio ao Pequeno Agricultor (CAPA). Esta família produz e vende na feira: alface, almeirão, cebolinha, brócolis, couve flor, beterraba, cenoura, queijo, doce de leite, açúcar mascavo, melado, mel, ovos, pão de queijo e geléias, além do preparo da tapioca durante as feiras.

Outra família que participava desta feira morava da comunidade de Alto Alegre. Eles não produziam alimentos agroecológicos, pois compravam as mudas e sementes nas agropecuárias locais. Os produtos comercializados na feira eram alface, chicória, couve, cebolinha, salsinha, beterraba, repolho, ovos e bolachas, porém, acabaram desistindo desta produção e migrando para Santa Catarina em março de 2016. "Seu lugar" na feira foi ocupado por outro agricultor de Ampére, que comercializa frutas (laranja e bergamota), verduras, tubérculos e frango, todos convencionais.

Considerando o grupo inicial, este foi o último a ser integrado a feira, 4 ou 5 meses depois dos demais, talvez por isto ainda não possui uma barraca coberta, que está sendo providenciada junto à Prefeitura Municipal. 0 produtor rural também trabalha alguns dias da semana de pedreiro, na cidade 
de Ampére, para complementar a renda familiar, já que o estabelecimento onde mora com sua família é muito pequeno e a produção não é suficiente para suprir os gastos da mesma.

Outro produtor tem se dedicado principalmente ao cultivo da cana-de-açúcar e da banana. Ele relatou que a maior parte da renda da família é gerada com a produção e venda das bananas, no entanto, ele também comercializa alface, ovos, mandioca, bolachas e doces (Imagem 03).

Acompanhando a feira da praça Reinaldo Simonetto, podemos destacar a importância da Universidade, seja pública ou privada, no trabalho direto com os agricultores. A FAMPER teve um papel fundamental na organização inicial, bem como na conquista do espaço para comercialização. Apesar das dificuldades e das divergências de ideias entre alguns feirantes, estes buscaram outro espaço na cidade, a praça pública, lugar de estreitamento dos laços entre os feirantes e os consumidores, conforme pudemos verificar nos trabalhos de campo realizados.

Figura 3. Barraca na feira da Praça Reinaldo Simonetti - Ampére.

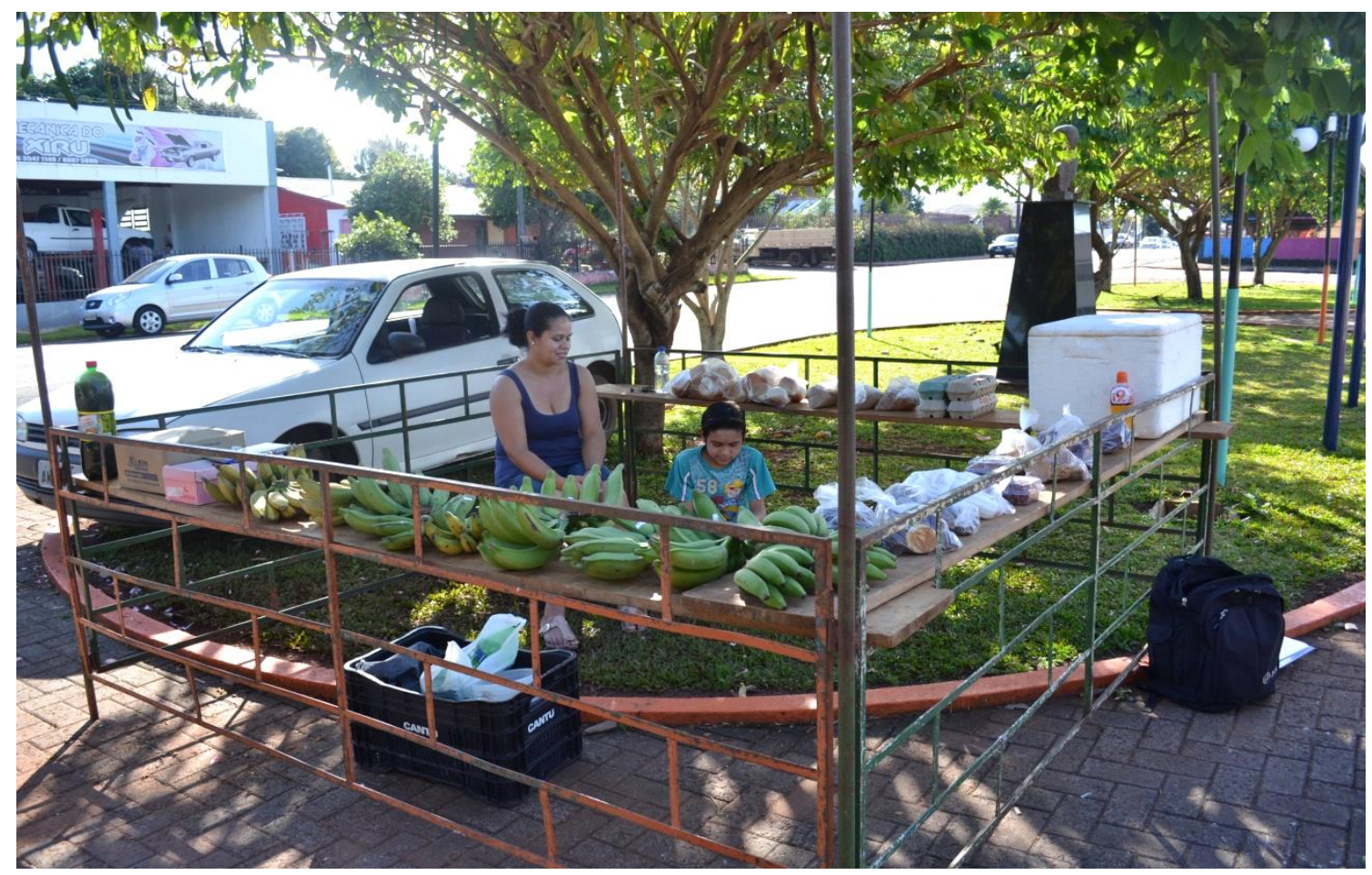

Fonte: Arquivo do GETERR/UNIOESTE - Trabalho de campo realizado em julho de 2015.

Em virtude do baixíssimo investimento do poder público municipal para a instalação dos feirantes, estes estão sempre buscando melhorias, tanto na disposição dos produtos nas barracas, como na produção. Também não há assistência técnica por parte das entidades locais, alguns produtores comentaram que já receberam visitas dos técnicos do CAPA - Verê e até foi feito pedido de certificação, porém, este processo ainda não foi concluído. 
Além da participação nesta feira, parte dos feirantes da Praça Reinaldo Simonetto informaram que também realizam outra, toda sexta-feira, na praça central de Ampére, onde trabalham com outros agricultores, vendendo vinho, queijo, bolachas, verduras e panificados.

\section{A Feira Municipal de Flor da Serra do Sul}

A feira livre realizada na cidade de Flor da Serra do Sul é a mais recente dos municípios estudados, teve início no mês de maio de 2015, a partir das Conferências do PAA e do PNAE organizadas pela Prefeitura Municipal de Flor da Serra com os produtores rurais: decidiram realizar a feira aos sábados pela manhã para comercializar o excedente da produção familiar.

Inicialmente, a feira contava com 9 famílias de agricultores, atualmente, um ano após o início, a feira conta com apenas 5 famílias (Imagem 04). Algumas das dificuldades na comercialização acabaram fazendo com que parte das famílias desistissem da participação na feira. Uma das nossas entrevistadas afirmou que, inicialmente, alguns feirantes tinham preços acima dos supermercados locais e, dessa forma, os consumidores preferiam comprar os mesmos produtos nestes últimos, fato que acabou gerando a desistência de alguns feirantes. Ela ainda nos conta que há grande dificuldade em convencer os produtores de que o ajuste nos preços é necessário, porque a venda na feira é excedente e que é mais viável tendo um preço mais acessível para o consumidor.

Entre os feirantes, o tamanho médio dos estabelecimentos rurais é de 11,5 ha, onde trabalham pequenas famílias (média de 3 pessoas), utilizando um trator de uma associação comunitária, adubação orgânica e basicamente a força braçal naquilo que se vende na feira: batatadoce, mandioca, laranja, bergamota, ovos, verduras (alface, couve, repolho, rúcula), feijão, queijo, tempero verde, açúcar mascavo, melado, cenoura, almeirão, geléias, pães, cucas, bolos, bolachas, macarrão etc. Atualmente a principal instituição mediadora na organização e efetivação da feira é a Associação Institucional da Agricultura Familiar (ASSINTRAF).

Em trabalho de campo realizado na feira de Flor da Serra do Sul, os produtores relataram que o espaço onde vendem foi cedido pelo Sistema de Cooperativas de Crédito do Brasil (SICOB), portanto, é privado e a localização propicia pouca visibilidade na cidade, apesar de estar no centro da mesma. Quando não está frio e não chove, os feirantes montam barracas improvisadas em uma praça pública da cidade.

Três famílias que participam da feira também vendem parte da produção para o Programa de Aquisição de Alimentos (PAA) e Programa Nacional de Alimentação Escolar (PNAE); alguns também comercializam em bairros das cidades de Flor da Serra e Salgado Filho e, simultaneamente, em algumas comunidades rurais de Flor da Serra! 
Figura 4. Feira municipal de Flor da Serra do Sul.

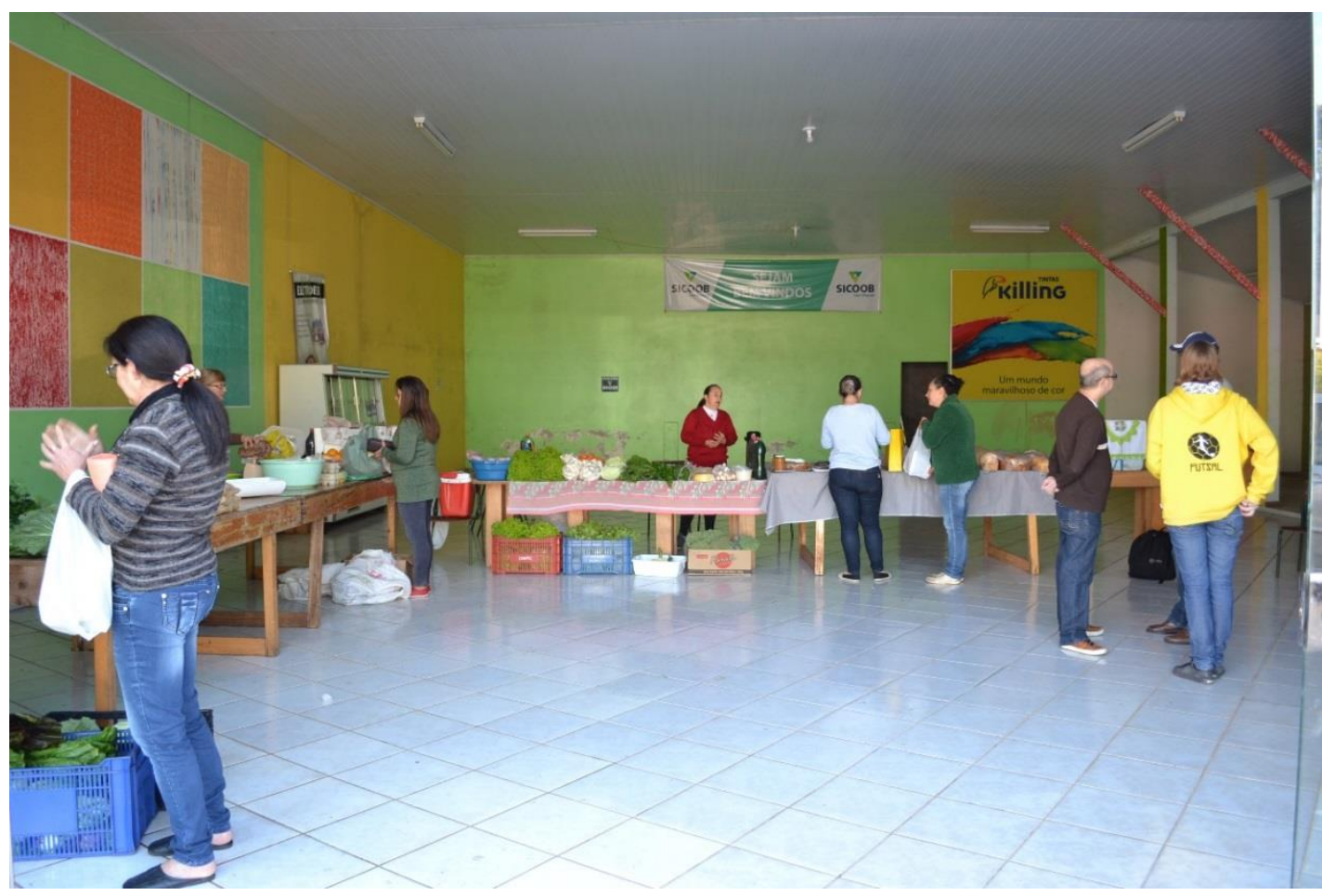

Fonte: Banco de dados GETERR/UNIOESTE - Trabalho de campo realizado em 07/2016.

No caso do PAA/PNAE, cabe ressaltar que o cardápio da alimentação escolar é elaborado semanalmente pela nutricionista da Prefeitura Municipal, esta relatou que define a partir da produção e disponibilidade dos produtos, mediando a entrega com o sistema de trocas, no qual os agricultores se organizam e revezam a produção dos alimentos para que todos possam entregar uma diversidade maior, qualificando a alimentação dos alunos.

\section{A Feira Ecológica da CANGO - Francisco Beltrão}

A Feira Ecológica da CANGO acontece toda sexta-feira de manhã, no bairro da CANGO, cidade Norte. Ela foi um dos resultados do Projeto Vida na Roça, a partir de 1996, numa parceria entre a Faculdade de Ciências Humanas de Francisco Beltrão (FACIBEL), a Universidade Estadual do Oeste do Paraná (UNIOESTE) e Associação de Estudos, Orientação e Assistência Rural (ASSESOAR).

Desde 1990, discutia-se como fazer uma feira diferenciada, através do processo de formação da Escola Comunitária de Agricultores (ECA), dinamizada pela ASSESOAR, desde 1991. Nas atividades de formação das ECAs, os agricultores se reuniam para estudar e se organizar politicamente, criando a ideia e meta de criar uma feira livre.

Eduardo (2014) descreve sobre a trajetória dos feirantes ecológicos da CANGO: 
A feira livre destaca-se dentre as formas de venda direta. Antes de 1997, alguns agricultores, hoje integrantes da Associação das Agricultoras e Agricultores Ecológicos, participavam da feira livre do Calçadão (Feira do Produtor Rural de Francisco Beltrão realizada duas vezes por semana [...]), no centro da cidade de Francisco Beltrão. Na feira, a maior do município e ainda em operação, não existia (e ainda não há) um direcionamento político mais específico em matéria de agroecologia. 0 conflito entre as perspectivas convencional e agroecológica, de produção e de organização da feira, levaram alguns produtores a romperem com a feira do Calçadão e estruturarem outra proposta, exclusivamente destinada a comercialização de produtos agroecológicos, desde 1997, situada no Bairro CANGO, em frente à sede da ASSESOAR: local onde até hoje, às sextas-feiras pela manhã, são armados os gazebos abrigando as placas de madeira, apoiadas em cavaletes, onde expõem-se os produtos para comercialização (EDUARDO, 2014, p. 299).

Atualmente, a Feira Ecológica da CANGO é realizada na frente da Cooperativa da Agricultura Familiar Integrada de Francisco Beltrão (COOPAFI), também na cidade Norte. A mudança do local da feira era um anseio de alguns produtores, pois a localização anterior não era muito boa, os consumidores acabavam não visualizando os feirantes. Desde o início de 2016 a feira tem nova localização e conta com um espaço maior, mais visível aos consumidores e com geladeiras para conservar os produtos que precisam ser resfriados (Imagem 05).

Nesta feira, participam seis famílias de agricultores e, durante o acompanhamento que fizemos, um dos produtores desistiu, começou a participar de outra, da Feira dos Produtores do Bairro Vila Nova, localizada na porção Leste da cidade de Francisco Beltrão: o motivo foi a baixa venda na feira da CANGO (Gráfico 01), e alguns conflitos com outro feirante que começou a participar em 2012 e acabou tendo a preferência nas vendas, diminuindo, ao que parece, a comercialização dos demais feirantes. Além deste produtor, outro também começou a participar da Feira da Vila Nova, permanecendo na da CANGO.

Das cinco famílias que participam regularmente da feira da CANGO, nenhuma tem a renda unicamente desta atividade, alguns recebem aposentadoria por idade, outros realizam trabalhos assalariados na cidade para completar a renda familiar. Todas as propriedades são familiares, a área total das cinco famílias é de aproximadamente 36 ha e todos produzem agroecologicamente, com a certificação da Rede Ecovida de Agroecologia. 
Figura 5: Atual localização da Feira Ecológica da CANGO.

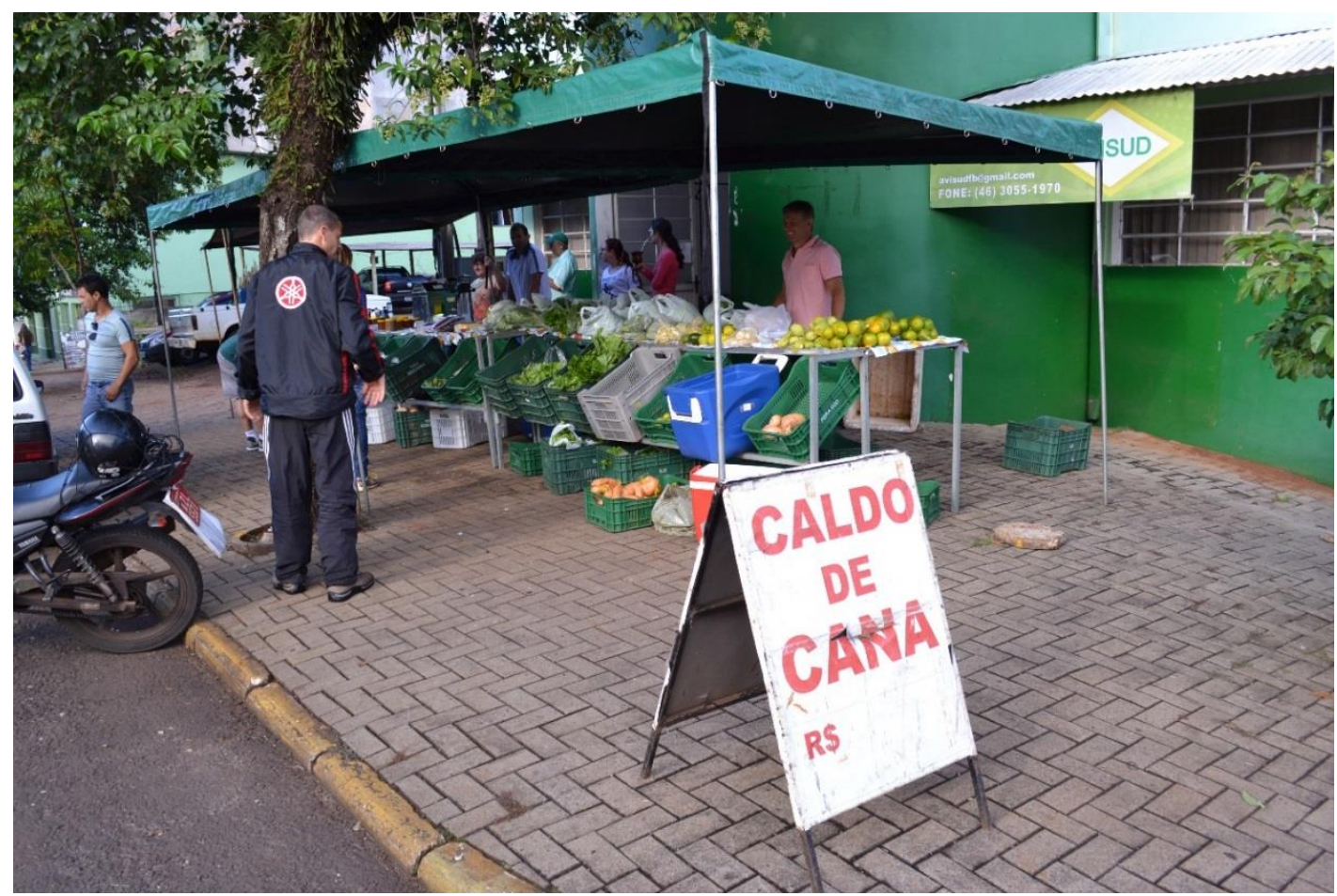

Fonte: Banco de dados GETERR/UNIOESTE - Trabalho de campo realizado em 04/2016.

Gráfico 1: Comparativo dos produtos disponibilizados pelo mesmo produtor nas feiras CANGO e Vila Nova (maio/2015).

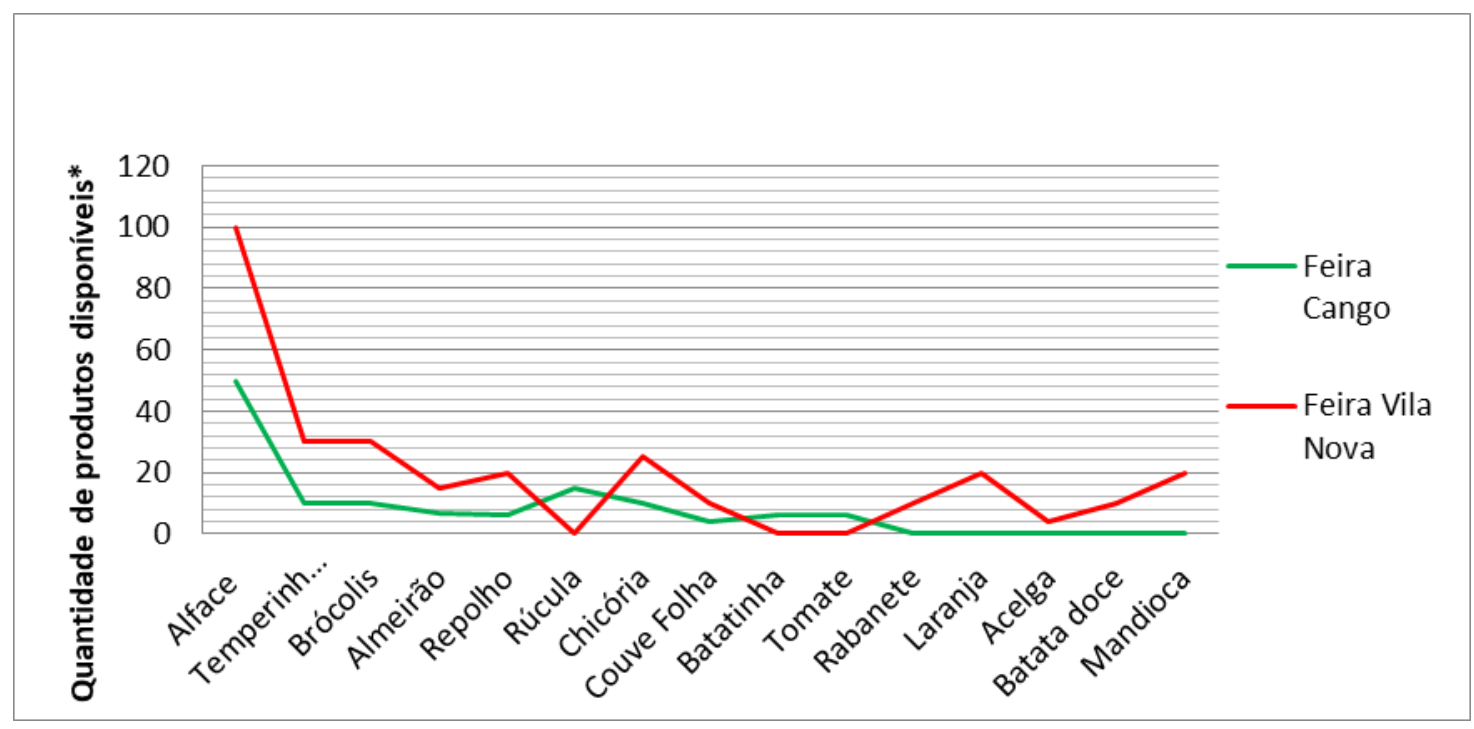

Fonte: Trabalhos de campo (2015). Organização: MEIRA, R. A. (2016).

*Na quantidade de produtos consideramos diferentes unidades de medida: kg, maço, pacote, dúzia, litro e peça.

Os principais alimentos comercializados, a partir do que identificamos nas visitas periódicas (2014-2016), são: abóbora, abobrinha, acelga, açúcar mascavo, agrião, alface, alho, almeirão, amendoim, arroz, banana, batata-doce, bergamota, beterraba, bolachas, brócolis, caqui, cebola, 
cebolinha, cenoura, chicória, chuchu, couve, couve-flor, doces, ervilha, feijão, laranja, lima, limão, macarrão, mandioca, manteiga, milho, moranga, morango, pão, pepino, pêssego, pimentão, queijo, rabanete, repolho, rúcula, salsa, tangerina, tomate, trigo, uva, vagem. No Gráfico 02 apresentamos o acompanhamento anual da quantidade vendida de alguns produtos na feira CANGO.

Como podemos perceber, predomina a venda de verduras, legumes e panificados, tanto pela facilidade na produção como pela procura na feira. Produtos como queijo, leite e ovos, são vendidos em menor quantidade se comparados com os demais, no entanto, têm um bom retorno financeiro para os feirantes, assim como as geléias. Já a produção e comercialização das frutas, dependem muito de cada estação do ano.

É quase unanimidade entre os feirantes a queixa feita em relação à pouca participação, na atualidade, da ASSESOAR, na organização e divulgação da feira, bem como na busca por melhorias, principalmente com o poder público municipal. Parece que há um hiato político entre os feirantes e as instituições supracitadas, principalmente com os dirigentes municipais, fato que prejudica a conquista de melhorias e da possível ampliação desta feira. Já a atuação do Sindicato dos Trabalhadores Rurais (STR) local e da COOPAFI parece ser bastante significativa em virtude das falas dos feirantes, principalmente pelas mediações feitas no PNAE e no PAA.

Gráfico 2: Produtos vendidos na Feira Agroecológica da CANGO - Francisco Beltrão (7/2014 - 6/2015).

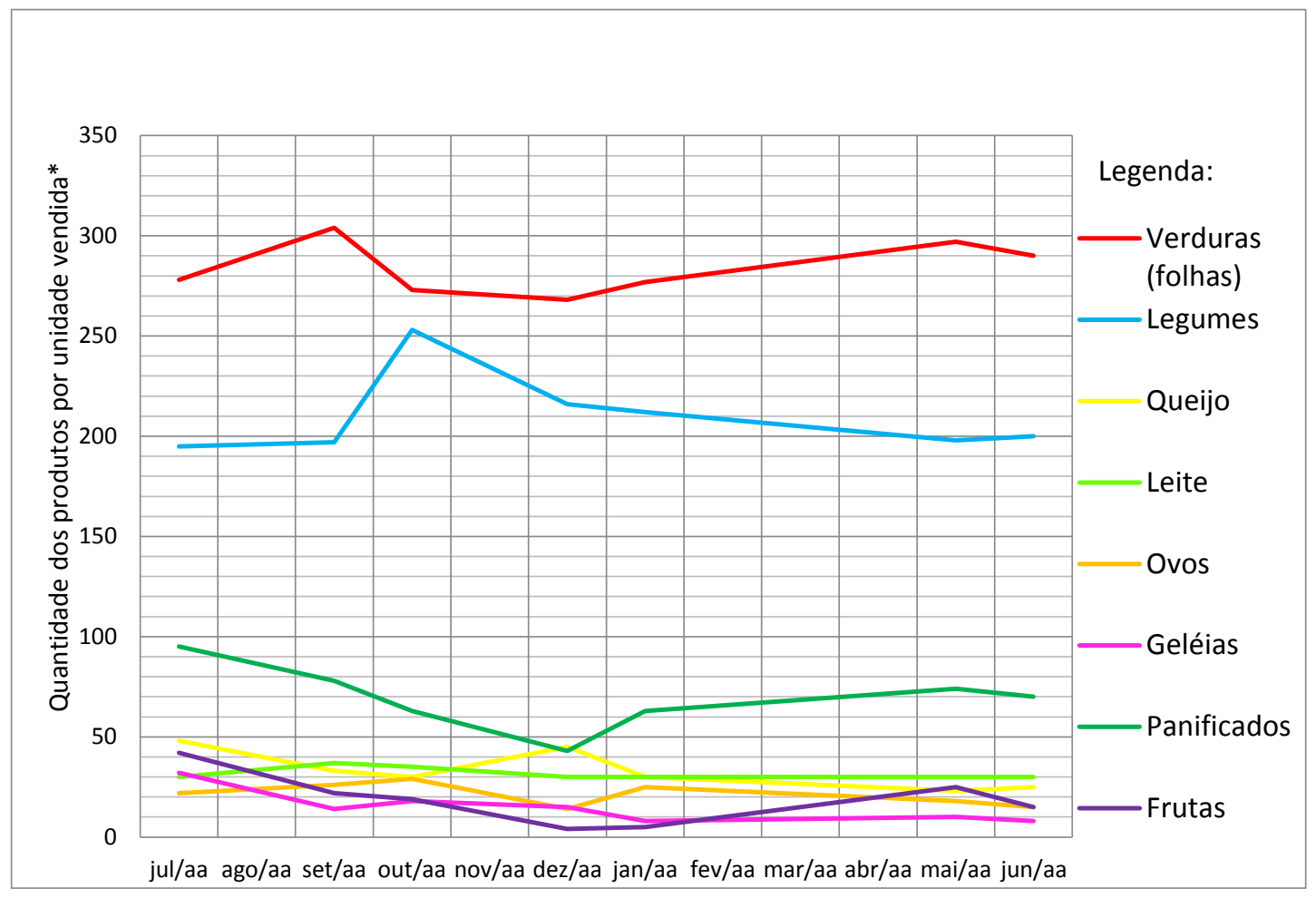

Fonte: Trabalhos de campo (2014 e 2015). Organização: MEIRA, R. A. (2015).

*Na quantidade de produtos consideramos diferentes unidades de medida: kg, maço, pacote, dúzia, litro e peça. 
Apesar das dificuldades que os feirantes mencionaram, o espaço da feira possibilita o encontro semanal com outras pessoas, a aprendizagem e o ensino, gerando conhecimento tanto para eles como para os consumidores. Os produtores, ao se deslocarem para a cidade e ali se instalarem todas as semanas, trocam experiências, criam vínculos de amizade e confiança com os consumidores, fatos muito recorrentes na feira da CANGO, reproduzindo-se relações próximas nos níveis pessoal, político e espacial, pois a grande parte dos seus clientes são do Bairro CANGO e de outros proximamente localizados.

\section{Feira dos Agricultures Familiares do Bairro Vila Nova - Francisco Beltrão}

Consoante já citamos, esta feira surgiu de uma dissidência, a partir do anseio de alguns agricultores da Associação de Produtores Ecológicos de Francisco Beltrão, que participavam da Feira da CANGO, descrita anteriormente, pois consideravam importante e mais rentável realizarem a feira duas vezes por semana. A feira dos Agricultores Familiares, realizada no Bairro Vila Nova (Imagem 06), iniciou suas atividades em outubro de 2014, numa fase inicial e experimental, com 3 produtores orgânicos (certificados pela Rede Ecovida de Agroecologia) e 5 convencionais, porém, todos familiares; esta conjugação foi decidida em reunião realizada antes do início da feira, para possibilitar a participação de outros agricultores, que não tinham produção agroecológica, já que estes não conseguiam entrar na associação da feira do centro (de Francisco Beltrão) e não podiam participar da Feira Agroecológica da CANGO.

Desde o início da feira, estamos acompanhando a comercialização dos produtores. Durante este acompanhamento verificamos a ótima aceitação que a feira teve no bairro, bem como a satisfação dos produtores: um deles, que participava da Feira da CANGO, está participando somente desta nova feira, justamente em virtude do aumento das vendas na Vila Nova. Ao mesmo tempo, é importante registrar que 2 continuam participando da Feira Ecológica da CANGO. Estes agricultores ainda não possuem o estatuto da feira, mas estão elaborando a partir do da Feira da CANGO.

Os produtores que não possuem certificação comercializam alho, chás, frutas, geléias, mel, melado, ovos, panificados, pastel, peixe, salame, tortas salgadas e vinagre. Já os certificados vendem abacate, abobrinha, acelga, açúcar mascavo, alface americana, alface crespa, alface mimosa, alface roxa, almeirão, batata-doce, batata salsa, batatinha, brócolis, cenoura, chicória, couve-flor, couve folha, espinafre, feijão preto, laranja, mandioca, moranga, ovos, pepino, pimentão, queijo, rabanete, repolho, rúcula, salsa e cebolinha. No Gráfico 03, apresentamos alguns dados referentes ao acompanhamento de um ano da comercialização na feira do Bairro Vila Nova. 
Figura 6: Feira dos Agricultores Familiares, Bairro Vila Nova - Francisco Beltrão.

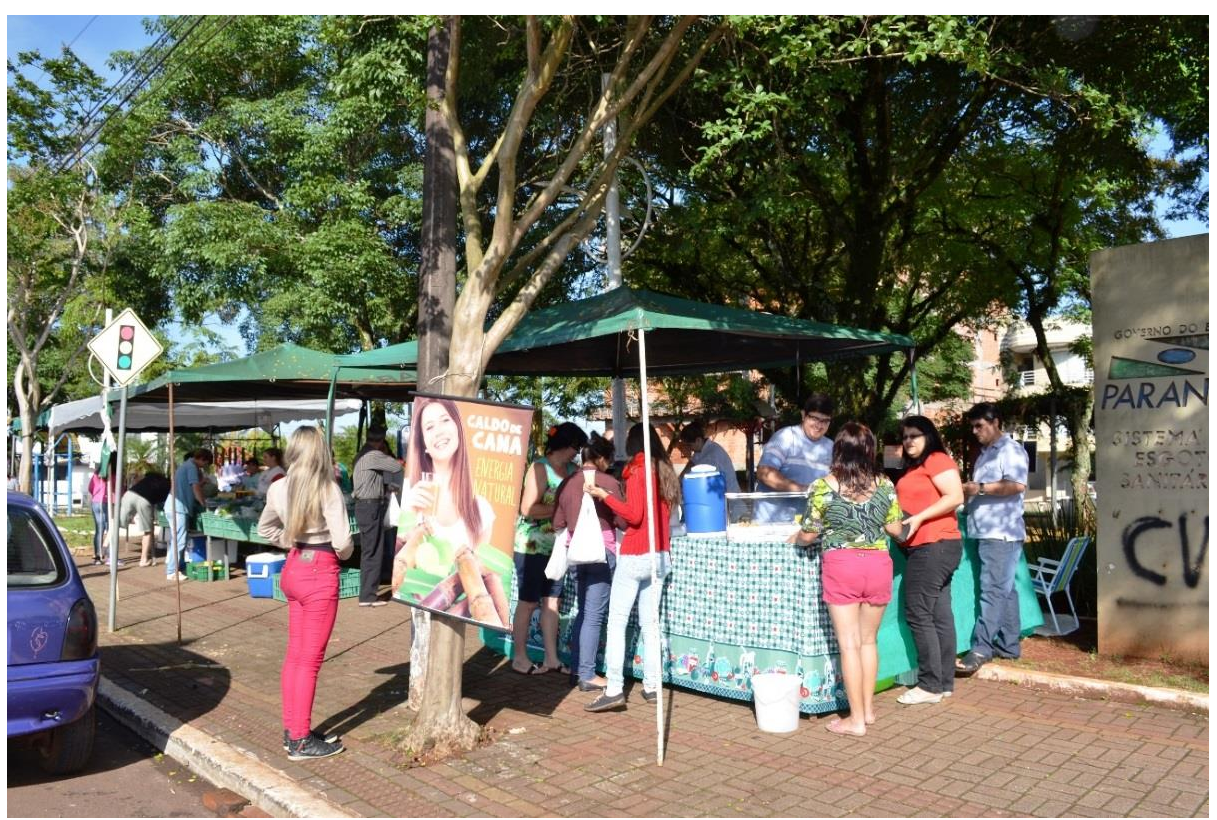

Fonte: Banco de dados GETERR/UNIOESTE - Trabalho de campo realizado em 11/2014.

Gráfico 3: Produtos vendidos na Feira Vila Nova - Francisco Beltrão (11/2014-10/2015).

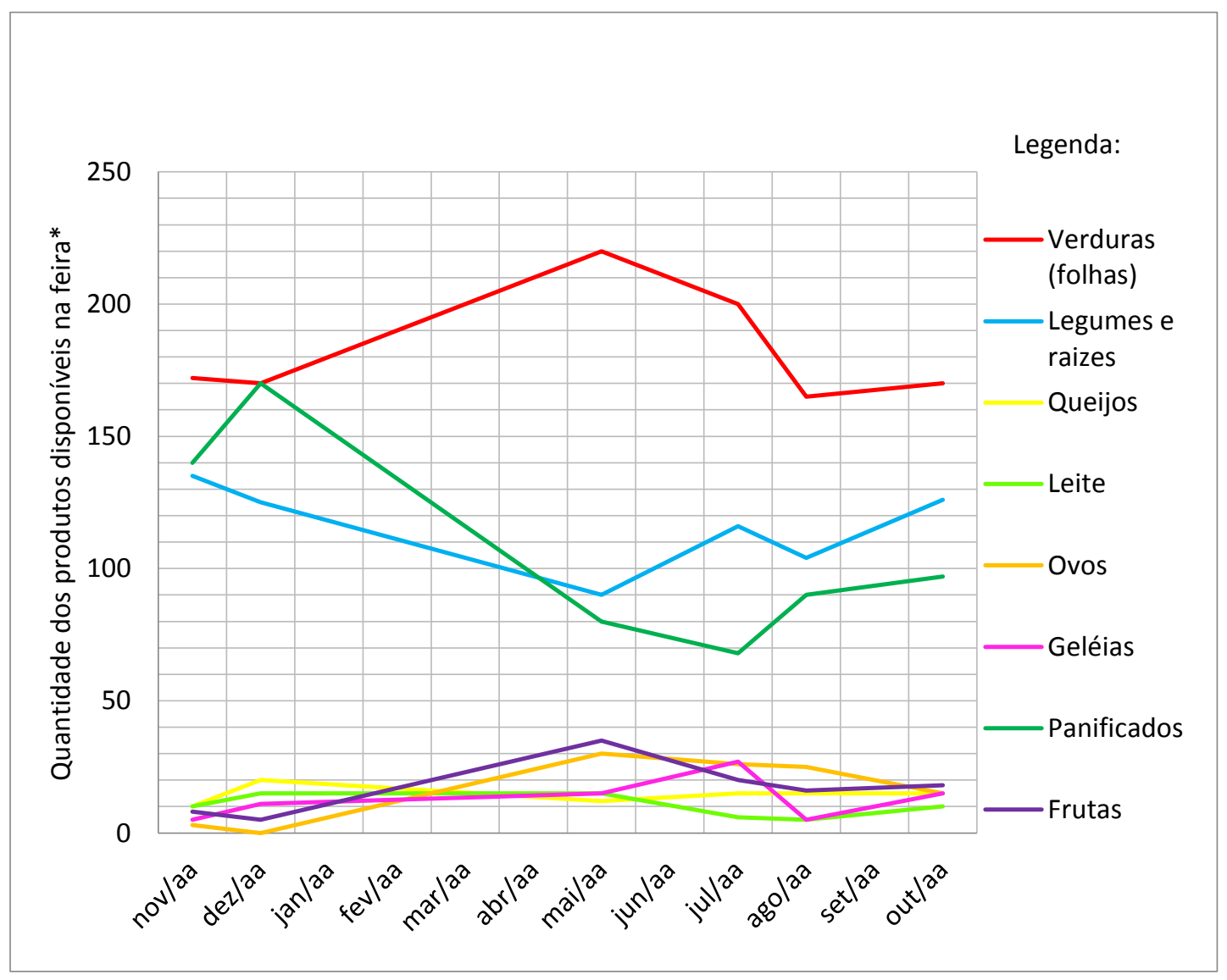

Fonte: Trabalhos de campo (2014 e 2015). Organização: MEIRA, R. A. (2015).

*Na quantidade de produtos consideramos diferentes unidades de medida: kg, maço, pacote, dúzia, litro e peça. 
Assim, notamos que as vendas mais expressivas são de verduras, legumes e panificados, como ocorre na Feira da CANGO, embora os períodos sejam um pouco distintos. Apesar da queda nas vendas em alguns dias de feira (quase sempre relacionados a dias de feriado prolongado), segundo os feirantes, não é algo que afete significativamente a comercialização mensal. E este aspecto é muito importante, pois sua reprodução biológica e social requer, necessariamente, insistência e resistência, seja em relação às intempéries, seja no que se refere às oscilações do mercado e à luta que precisam efetivar para tentar conseguir melhores condições de trabalho e vida cotidiana.

Os feirantes se dizem muito satisfeitos com a nova feira e os moradores do bairro aderiram e gostaram da instalação da feira no mesmo. Os vendedores relatam que estão se adaptando ao ritmo dos consumidores do bairro, muitos já fazem seus pedidos da semana com antecedência. A integração entre os feirantes, que são todos agricultores, e os consumidores, aproxima e cria a interação entre moradores do campo e cidade. Os elos se criam para além do espaço da feira, são vínculos de confiança, que começam desde a produção do que será comercializado e que chegará na mesa dos consumidores. A Feira Vila Nova, no nosso entendimento, é mais um processo da auto-organização dos agricultores, pois toda coordenação da feira foi pensada e efetuada pelo grupo, sem que qualquer instituição prestasse alguma mediação para tal.

\section{A Expansão: as Feiras do Coletivo de Mulheres Agricultoras de Francisco Beltrão}

A primeira feira realizada pelo Coletivo de Mulheres Agricultoras de Francisco Beltrão, aconteceu na praça central da cidade, em 5 de julho de 2014 (Imagem 07) em parceria com a Prefeitura Municipal de Francisco Beltrão (Secretaria de Desenvolvimento Rural), com o Sindicato dos Trabalhadores Rurais (STR - FB), com representantes do Bairro Padre Ulrico e com a Universidade Estadual do Oeste do Paraná/Grupo de Estudos Territoriais (UNIOESTE/GETERR), que levou o nome de Feira dos Saberes e Sabores.

A realização desta feira teve o objetivo principal de divulgar a produção de alimentos familiares, especialmente a partir da participação das mulheres. Na feira, notamos a participação efetiva das mulheres e dos homens (com alguns jovens - no total, participaram 23 famílias) mobilizados a partir das discussões feitas no Coletivo de Mulheres e em virtude do planejamento resultante da decisão de realização da feira envolvendo, também, algumas famílias (3) do Bairro Padre Ulrico - Francisco Beltrão.

No dia da feira, aos poucos, a circulação das pessoas foi aumentando no local, especialmente em virtude da divulgação feita por meio da mídia escrita e falada, com destaque para a Rádio Comunitária Anawin. Acreditamos, também, que tal fato ocorreu em virtude da quantidade de 
produtos que estavam sendo vendidos pelas famílias, tais como frutas, verduras, plantas medicinais, pães, cucas, bolachas, tapetes, mandioca, pinhão etc.

Figura 7: Primeira Feira dos Saberes e Sabores - praça central de Francisco Beltrão.

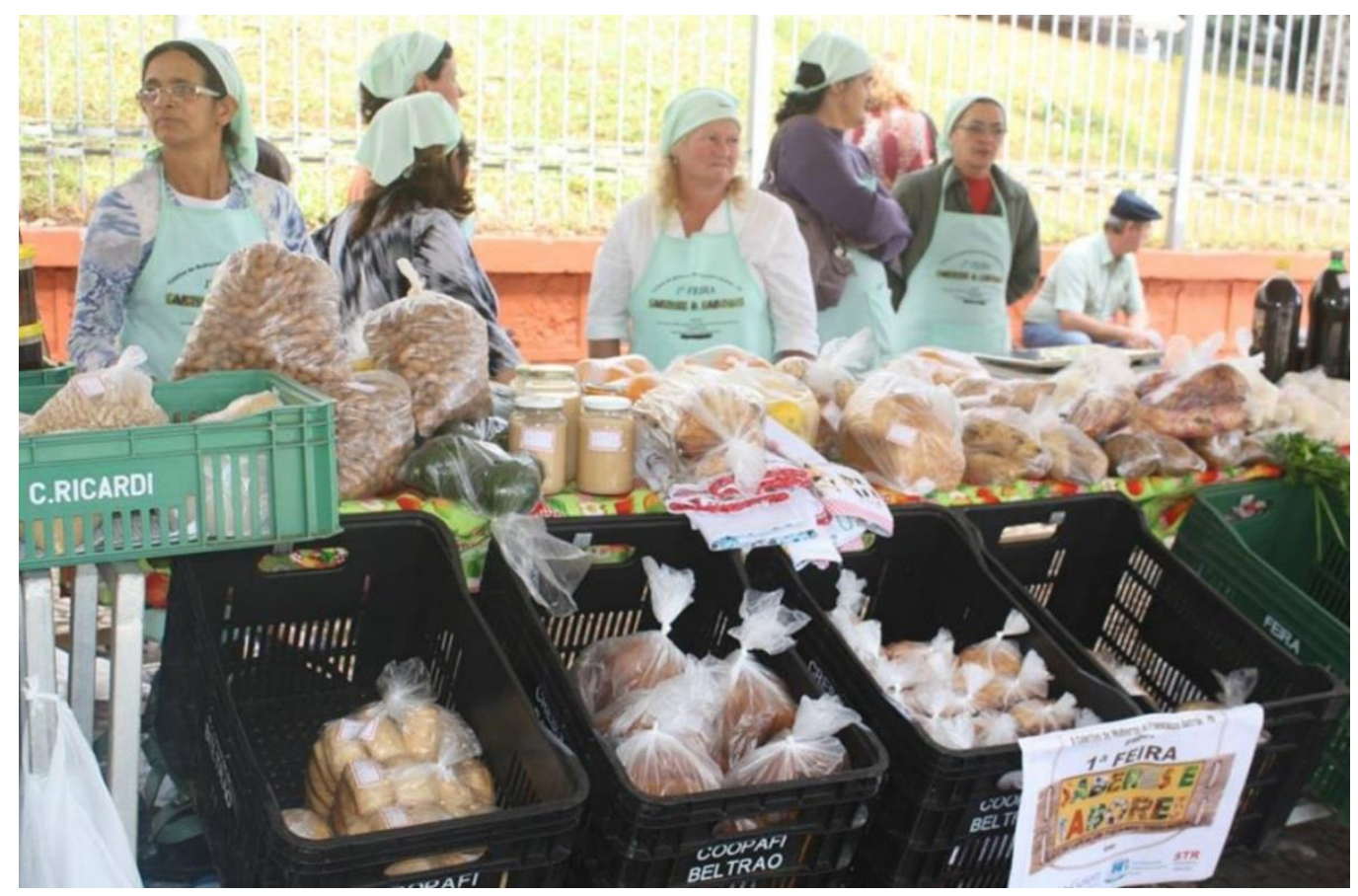

Fonte: Banco de dados GETERR/UNIOESTE - Trabalho de campo realizado em 07/2014.

Foram realizadas três Feiras dos Saberes e Sabores, depois o Coletivo, em parceria com a Secretaria de Desenvolvimento Rural, começou a realizar periodicamente a feira, em outro local, na praça do terminal urbano municipal. A iniciativa deu resultados positivos e, atualmente, são seis feiras organizadas pelo Coletivo de Mulheres Agricultoras de Francisco Beltrão. Todas as feiras ocorrem na sexta-feira, manhã e tarde, cada uma em um bairro diferente da cidade. No início, o auxílio da Secretaria de Desenvolvimento Rural se fazia mais necessário, atualmente, as mulheres já estão mais organizadas e independentes, em virtude do intenso trabalho de organização do Coletivo, aspecto que valoriza ainda mais os processos de auto-organização identificados, a partir da mobilização política, da (in)formação, da produção e comercialização de alimentos, da reprodução das relações de solidariedade e confiança, interligando continuadamente as gentes do rural e do urbano por meio da circulação (e comunicação) de pessoas, informações e produtos.

\section{A Feira Livre de Marmeleiro}

A Associação dos Feirantes de Marmeleiro, juntamente com sua feira, foi criada em 17/9/2011, com apoio da Prefeitura Municipal e da Empresa Paranaense de Assistência Técnica e Extensão Rural (EMATER) 
e sempre é realizada aos sábados de manhã (a infraestrutura das barracas é montada pela Prefeitura Municipal), gerando certa dinâmica na praça central da cidade, com maior movimentação de pessoas. Em 2013, reunia 11 feirantes que comercializavam repolho, açúcar mascavo, alface, cenoura, chá para o chimarrão, alho, espinafre, batata-doce, laranja, lima, temperos verdes, mandioca, feijão etc., produção que variou, evidentemente, conforme as estações do ano. Na feira, também vendiam pães, bolachas, cucas, geléias, melado, mel e ovos, produções comuns entre os agricultores e feirantes, aspecto por nós já evidenciado.

Durante o ano de 2014, os produtos vendidos na feira de Marmeleiro, foram pimentão, milho verde, mandioca, couve, rúcula, feijão, temperos, pipoca, amendoim, limão, batata-doce, chuchu, abóbora, alface, moranga, cenoura, bergamota. Os mais vendidos foram mandioca e pimentão. Na feira, também vendiam pães, cucas e bolachas. É interessante notar que, em Marmeleiro, entre 2011 e 2013, a produção da mandioca diminuiu, apesar da sua importância para venda e alimentação familiar, em virtude da falta de gente para trabalhar; antes, tinham a motivação pela facilidade de vender para a fecularia de Realeza (PR).

Mergulhando nos dados históricos da feira de Marmeleiro, entre 3/2014 e 4/2015, notamos alguns aspectos relevantes: a) o número de feirantes oscila entre 2 e 7 (1 vende pastéis); b) os produtos mais vendidos, em ordem decrescente, foram os seguintes: alface, brócolis, mandioca, feijão, repolho, milho verde, cenoura e rúcula; c) houve importante complemento de renda com a venda de queijos, salames, ovos, mel e vinagre; d) entre os feirantes, houve uma média de 3 vendendo hortaliças, legumes e panificados; e) apenas um tem seu estabelecimento bem diversificado, produzindo e comercializando na feira verduras, legumes, panificados e produtos transformados artesanalmente (açúcar mascavo, melado, queijo, suco de uva e vinagre); f) os produtos comercializados na feira são, de fato, em pequeníssimas quantidades; g) apenas 1 é agroecológico (Imagem 08).

Além da Prefeitura Municipal e da EMATER, já mencionadas, em Marmeleiro, os agricultores entrevistados destacam outras instituições importantes para eles, tais como: a) a Cooperativa de Comercialização da Agricultura Familiar Integrada (COOPAFI), pois adquire parte da produção para utilização na merenda escolar em Marmeleiro; b) o STR local, porque atua no nível de organização política dos agricultores; c) a CRESOL, apesar de "não financiar a agricultura orgânica".

Nas falas dos agricultores aparecem informações muito relevantes, revelando que, em Marmeleiro, não há apoio institucional bem definido em favor da Agroecologia e há problemas de várias ordens: apesar do resgate de algumas sementes, tais como couve, brócolis, tomate, milho e cebola, faltam sementes; faltam subsídios e/ou financiamentos públicos para preservar a água, a terra, os animais e as florestas: quando conseguem algum financiamento, por exemplo, não há Programa de Garantia da Atividade Agropecuária (PROAGRO); há "doenças" dificilmente controláveis (como a ferrugem) e carecem de produtos específicos mais eficientes para combater os insetos e as lagartas; há pouca gente para trabalhar na produção, no empacotamento e na comercialização; demora para a certificação, intempéries etc. 
Figura 8: Feira livre de Marmeleiro.

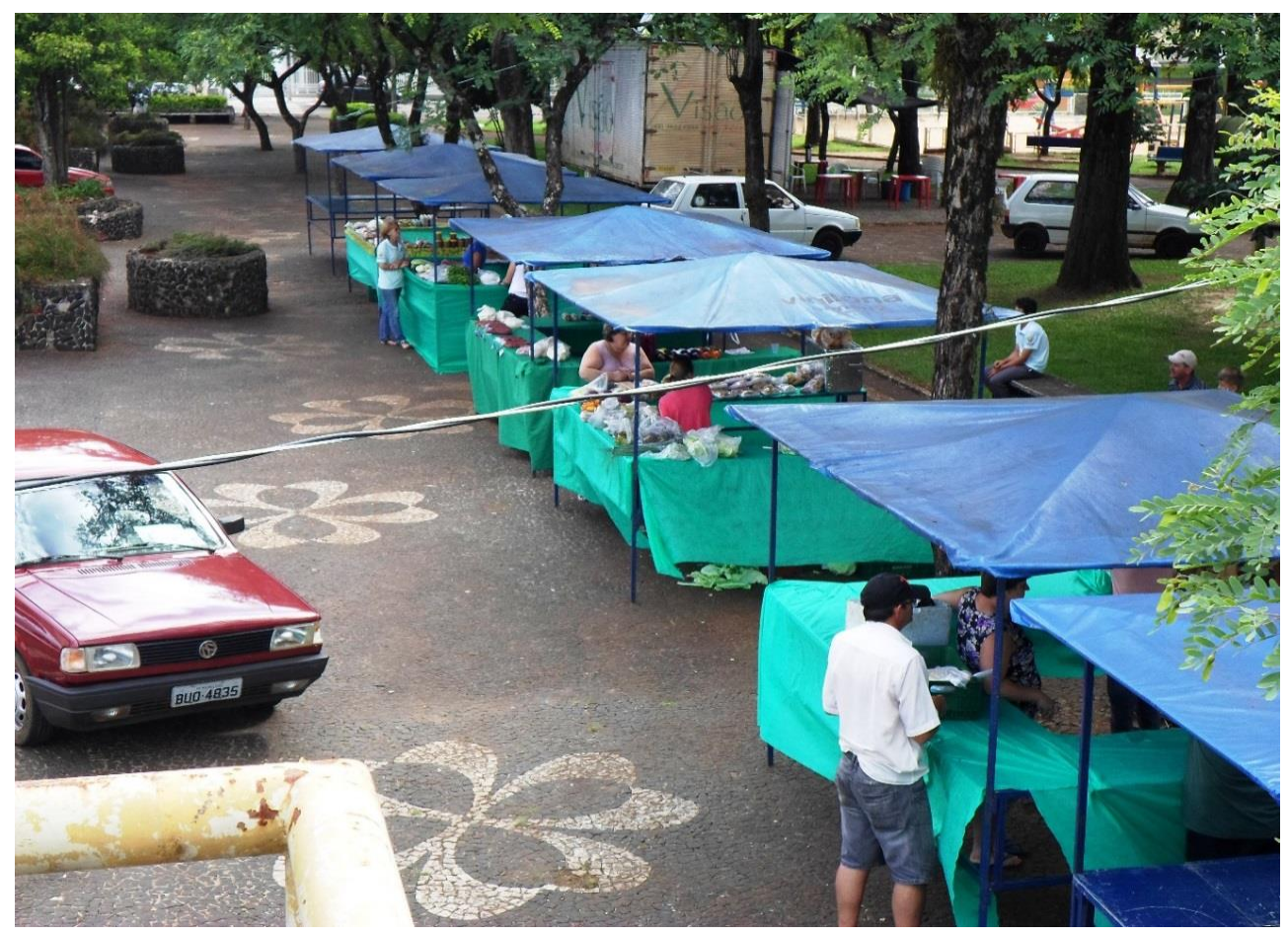

Fonte: Banco de dados GETERR/UNIOESTE - Trabalho de campo realizado em 06/2014.

Desse modo, podemos inferir que as feiras livres são realizadas por produtores de base camponesa e familiar, trabalhando com sua força física e técnicas rudimentares, produzindo alimentos agroecológicos e convencionais, vendendo-os semanalmente in natura e transformados artesanalmente. As feiras complementam a renda familiar, sendo uma das objetivações cotidianas da reprodução camponesa e da articulação existente entre os espaços rurais e urbanos nos municípios em questão.

\section{CONSIDERAÇÕES FINAIS}

As redes de comercialização construídas por meio das feiras livres, perpassam a ideia de comércio na cidade, elas contribuem para revitalizar o espaço urbano, modificam a dinâmica do bairro onde estão instaladas e da cidade - mesmo que temporariamente-, são responsáveis pela valorização do que é produzido localmente e uma forma de conexão direta entre produtores e consumidores.

As redes curtas que se estabelecem nos municípios estudados, são alternativas para além da hegemonia dos mercados e da produção industrializada. São uma fonte de renda complementar para os agricultores e uma importante opção para os consumidores, sobretudo em virtude das práticas agroecológicas efetivadas e da diversidade de alimentos que ali se encontra para aquisição e consumo: frutas, hortaliças, legumes, tubérculos, panificados, geléias, queijos, embutidos, conservas etc., 
revelando o uso diversificado do território e das respectivas condições ecossistêmicas de cada estabelecimento rural.

Nas articulações urbano-rurais construídas por meio das feiras livres, as principais instituições mediadoras são a ASSESOAR, a ASSINTRAF, a COOPAFI, o STR (Francisco Beltrão, Ampére e Marmeleiro), a UNIOESTE, a EMATER e a FAMPER, embora exista centralidade da auto-organização dos agricultores, especialmente por meio das suas associações e do Coletivo de Mulheres Agricultoras de Francisco Beltrão.

Apesar do amparo do poder público ser irrisório, constatamos que as feiras estão gerando importantes resultados econômicos, políticos e culturais para os produtores diretos e para os consumidores, contribuindo para reproduzir valores culturais como a solidariedade em relações próximas por motivos pessoais, políticos e culturais, juntamente com práticas sustentáveis como as agroecológicas (aproveitamento dos recursos de cada estabelecimento rural; produção de alimentos sem insumos químicos; uso diversificado do solo; reciclagem de matéria orgânica; valorização dos conhecimentos dos agricultores; concretização da comercialização direta com o consumidor etc.) e a auto-organização política, processo fundamental em movimentos ambientalistas e de resistência diante da produção agroquímica convencional. Portanto, consideramos de extrema necessidade que as municipalidades estejam mais voltadas para as necessidades dos agricultores e feirantes, pois estes precisam de assistência e de melhorias infraestruturais, em Flor da Serra, Marmeleiro, Ampére (no que se refere à feira da praça Simonetto) e Francisco Beltrão.

Sucintamente, entre 2013 e 2016, notamos uma considerável oscilação entre a quantidade de agricultores (agro)ecológicos certificados e os que estão em transição nos municípios pesquisados, justamente em razão das dificuldades que eles têm todos os dias para produzir, certificar, conservar e comercializar. Nossos entrevistados relataram que, normalmente, falta apoio das prefeituras municipais, bem como financiamento público específico para a produção agroecológica e gente para trabalhar em virtude da constante expropriação de moradores do espaço rural. Há uma substantiva carência de políticas públicas específicas, dialógicas e participativas, voltadas para as práticas agroecológicas e artesanais, "caminhando" mais sistemática e solidamente na direção da soberania e da segurança alimentar. Isto pode ocorrer por meio da intensificação e ampliação das redes curtas de produção, certificação e comercialização, sem intermediários, potencializando-se as relações próximas já existentes e criando outras, nos níveis pessoal, espacial, político e cultural.

\section{REFERÊNCIAS}

ALTIERI, Miguel. Agricultura familiar camponesa como patrimônio ecológico planetário. In: ALTIERI, M. Agroecologia: bases científicas para uma agricultura sustentável. São Paulo: Expressão Popular; 
Rio de Janeiro: AS-PTA, 2012 [2008]. p.363378.

. Agroecologia: a dinâmica produtiva da agricultura sustentável. Porto Alegre: Ed. UFRGS, 1998.

. Agroecologia: princípios e estratégias para o desenho de sistemas agrícolas sustentáveis. In: ALTIERI, M. Agroecologia: bases científicas para uma agricultura sustentável. São Paulo: Expressão Popular; Rio de Janeiro: AS-PTA, 2012 [2002a]. p.103-115.

. Manejo agroecológico dos recursos naturais em ambientes marginais. In: ALTIERI, M. Agroecologia: bases científicas para uma agricultura sustentável. São Paulo: Expressão Popular; Rio de Janeiro: AS-PTA, 2012 [2002b]. p.117-158.

ARRIEL SAQUET, Adriano et al. Agricultura ecológica e ensino superior: contribuições ao debate. Francisco Beltrão, PR: Grafit, 2005.

AUBRY, Christine e CHIFFOLEAU, Yuna. Le développment des circuits courts et l'agriculture periurbane: histoire, evolution en cours et questions actuelles, Innovations Agronomiques, n. 5, 2009, p. 53-67.

BARTRA, Armando. Campesindios: ethos, clase, predadores, paradigma.

Aproximaciones a una quimera. In: HIDALGO, F.; HOUTART, F. e LIZÁRRAGA, P. (Org.). Agriculturas campesinas en Latinoamérica - propuestas y desafios. Quito: Editorial IAEN, 2014. p. 269-276.

CHAFFOTTE, Lydie e CHIFFOLEAU, Yuna. Vente directe et circuits courts: évaluations, définitions et typologie, Les Cahiers de L'Oservatoire CROC, Montpellier, 2007, n. 1, p. 1-8.

CHAVEZ, Alejandro e SALCIDO, Gerardo. Gobernanza de los sistemas agroalimentarios localizados: el caso de los produtores rurales de nopal en Tlalnepantla, Morelos. México: Universidad Nacional Autónoma do México, 2014.

CHAYANOV, Alexander. La organización de la unidad económica campesina. Buenos Aires: Nueva Visi-ón, 1974.

DAROLT, Moacir. Circuitos curtos de comercialização de alimentos ecológicos: reconectando produtores e consumidores. In: NIEDERLE, P.; ALMEIDA, L.; VEZZANI, F. (Org.). Agroecologia: práticas, mercados e políticas para uma nova agricultura.

Curitiba: Kairós, 2013. p. 139-170.

DANSERO, Egidio e ZOBEL, B. Verso un dialogo tra comunità scientifica e comunità locale. In: Promozione della sostenibilità nel Pinerolese - un percorso di ricerca/azione territoriale. Turim: Euro Mountains, 2007. p.135-141.

DEMATTEIS, Giuseppe. Le metafore della terra. La geografia umana tra mito e scienza. Milano: Feltrinelli, 1985.

EDUARDO, Márcio Freitas. Transformando Terra em Território: construção e dinâmica do sistema local territorial agroecológico em Francisco Beltrão, Paraná. Tese de Doutorado, Programa de Pós-Graduação em Geografia. UNESP - Presidente Prudente, 2014.

ESCOBAR, Arturo. El final del salvaje: naturaleza, cultura y política en la antropologia contemporánea.

Colômbia/Santafé de Bogotá: ICAN/CEREC, 1999.

FERNANDES, Bernardo. MST: formação e territorialização. São Paulo: Hucitec, 1996. Formação e territorialização do MST no Brasil: 1979-2005. In: MARAFON, G.; RUA, J.; RIBEIRO, M. (Org.). Abordagens teórico-metodológicas em Geografia Agrária. Rio de Janeiro: Ed. UERJ, 2007. p.139-168. . Entrando nos territórios do território. In: PAULINO, E. e FABRINI, J. (Org.). Campesinato e territórios em disputa. São Paulo: Expressão Popular, 2008. p.273-301. Sobre a tipologia de territórios. In: SAQUET, M. e SPOSITO, E. (Org.). Territórios e territorialidades: teorias, processos e conflitos. São Paulo: Expressão Popular, 2009. p.197-215.

. Cuando la agricultura familiar es campesina. In: HIDALGO, F.; HOUTART, F. e LIZÁRRAGA, P. (Org.). Agriculturas campesinas en Latinoamérica - propuestas y desafios. Quito: Editorial IAEN, 2014. p. 1934.

GLIESSMAN, Stephen. Agroecologia: processos ecológicos em agricultura sustentável. Porto Alegre: Ed. UFRGS, 2000. GODOY, Wilson Itamar; ANJOS, Flavio Sacco. A importância das feiras livres ecológicas: um espaço de trocas e saberes da economia local. Revista Brasileira de Agroecologia. V. 2, 2007. Disponível em: http://www.aba- 
agroecologia.org.br/revistas/index.php/cad /article/view/1943>. Acesso em: $20 \mathrm{de}$ outubro de 2015.

GUZMÁN, Eduardo e MOLIVA, Manuel. Sobre a evolução do conceito de campesinato. São Paulo: Expressão Popular, 2005.

MAGNAGHI, Alberto. II progetto locale. Torino: Bollati Boringhieri, 2000. . II territorio nella crisi, Quaderni del territorio - ristrutturazione produttiva e nuova geografia della forza-lavoro, anno I, n.1. Milano: CELUC Libri, 1976. p.15-29.

MARQUES, Marta. Agricultura e campesinato no mundo e no Brasil: um renovado desafio à reflexão teórica. In: PAULINO, E. e FABRINI, J. (Org.). Campesinato e territórios em disputa. São Paulo: Expressão Popular, 2008. p. 49-78.

. Lugar do modo de vida tradicional na modernidade. In: OLIVEIRA, A. e MARQUES, M. (Org.). O campo no século XXI - território de vida, de luta e de construção da justiça social. São Paulo: Casa Amarela e Paz e Terra, 2004. p. 145-158.

De sem-terra a posseiro: a luta pela terra e a construção do território camponês no espaço da reforma agrária. Tese (Doutorado em Geografia Humana), USP, Departamento de Geografia, São Paulo, 2000.

MARTINS, José de S. O cativeiro da terra. São Paulo: Hucitec, 1986 [1979]. . Os camponeses e a política no Brasil. Petrópolis: Vozes, 1981.

MARX, Karl. O dezoito brumário de Louis Bonaparte. São Paulo: Centauro, 2000 [1852].

OLIVEIRA, Ariovaldo. Geografia agrária: perspectivas no início do século XXI. In: OLIVEIRA, A. e MARQUES, M. (Org.). $O$ campo no século XXI - território de vida, de luta e de construção da justiça social. São Paulo: Casa Amarela e Paz e Terra, 2004. p. 29-70.

. A geografia agrária e as

transformações territoriais recentes no campo brasileiro. In: CARLOS, Ana F. (Org.). Novos caminhos da geografia. São Paulo: Contexto, 1999. p.63-110.

. Agricultura camponesa no Brasil. São

Paulo: Contexto, 1991.

. Agricultura e indústria no Brasil.

Boletim Paulista de Geografia. n.58, AGB,
1981, p.5-64 (republicado na Revista

Campo-Território, v. 5, n. 10, 2010, p. 5-64). . Modo capitalista de produção e agricultura. São Paulo: Ática, 1986. POLANYI, Karl. A grande transformação. Rio de Janeiro: Campus, 2000 [1944].

RAFFESTIN, Claude. Por uma geografia do Poder. São Paulo: Ática, 1993 [1980].

RECH, Rogério. Aspectos socioeconômicos e de produção relacionados às feiras-livres do Sudoeste do Paraná. Dissertação de Mestrado. Universidade Tecnológica Federal do Paraná UTFPR, Pato Branco, 2011.

RENTING, Henk; MARSDEN, Terry; BANKS, Jo. Understanding alternative food networks: exploring the role of short food supply chains in rural developpment, Environment and Planning A, v. 35, 2003, p. 393-411.

SANTOS, José Erimar et al. Feira Livre como lugar privilegiado para a (Re)produção e (Re)invenção de Práticas Espaciais e Socioculturais Populares: a Feira Livre de Ceará-Mirim (RN), Sociedade e Território, Natal, v. 26, 2014. p. 58 - 75. Disponível em:< http://www.periodicos.ufrn.br/sociedadeeterr itorio/article/view/3523> Acesso em: 30 agosto 2015.

SANZ, Javier. Sistemas agroalimentarios locales y multifuncionalidad. Un enfoque de investigación en alimentos, ciencias sociales y territorio. In: RIVERA, M. (Org.). El desarrollo hoy hacia la construcción de nuevos paradigmas. México: UNAM - Instituto de Investigaciones Económicas, 2014. p. 87-103.

SAQUET, Marcos. Agricultura familiar: elementos teóricos de abordagem, Faz Ciência, v.1, n.1, 1997, p. 90-98.

. Abordagens e concepções de território. São Paulo: Expressão Popular, 2007.

. Contribuições teórico-metodológicas para uma abordagem territorial multidimensional em geografia agrária. In: SAQUET, M.; SUZUKI, J.; MARAFON, G. (Org.). Territorialidades e diversidade nos campos e nas cidades latinoamericanas e francesas. São Paulo: Expressão Popular, 2011. p.209-226.

. Os tempos e os territórios da colonização italiana. Porto Alegre: EST Edições, 2003 [2001].

. Por uma geografia das territorialidades e das temporalidades. Uma concepção multidimensional voltada para a cooperação e 
para o desenvolvimento territorial. Rio de Janeiro: Consequência, 2015 [2011].

SHANIN, Teodor. A definição de camponês: conceituações e desconceituações - o velho e o novo em uma discussão marxista, Revista Nera, ano 8, n.7, 2005, p. 1-21.

. La classe incómoda. Madri: Alianza Ed., 1983.

. Lições Camponesas. In: PAULINO, E. e FABRINI, J. (Org.). Campesinato e territórios em disputa. São Paulo: Expressão Popular, 2008. p. 23-47.
Peasantry as a political factor. In: SHANIN, T. (Org.). Peasants and peasant societies. Middlesex, Harmondsworth: Penguin Books, 1971. p. 238-263.

TAVARES DOS SANTOS, José. Colonos do vinho Estudo sobre a subordinação do trabalho camponês ao capital. São Paulo: Hucitec, 1978. THOMPSON, Edward. Costumes em comum: estudos sobre a cultura popular tradicional. São Paulo: Cia das Letras, 1998 [1991]. 